\title{
Isolation and characterization of a hydrogen peroxide resistant mutant of Bacillus subtilis
}

\author{
Orla M. Hartford f and Barbara C. A. Dowds \\ Author for correspondence: Barbara C. A. Dowds. Tel: +35316285222 . Fax: +35317083845 . \\ e-mail: BDOWDS@VAX1.MAY.IE
}

Department of Biology, St Patrick's College, Maynooth, Co. Kildare, Ireland

\begin{abstract}
A mutant of Bacillus subtilis has been isolated by continuous selection in increasing concentrations of $\mathrm{H}_{2} \mathrm{O}_{2}$. It grew with a doubling time of $85 \mathrm{~min}$ in minimal medium containing $150 \mathrm{mM} \mathrm{H}_{2} \mathrm{O}_{2}$, whereas the wild-type parent lysed in $100 \mathrm{mM} \mathrm{H}_{2} \mathrm{O}_{2}$. The mutant was also more resistant to organic peroxides than the wild-type. Further resistance to $\mathrm{H}_{2} \mathrm{O}_{2}$ could not be induced by pretreatment with low concentrations of the oxidant. The mutant synthesized a number of proteins at a much higher rate than the wild-type, including constitutive synthesis of all of the proteins which were induced by $\mathrm{H}_{2} \mathrm{O}_{2}$ in the wild-type. Four of these proteins were sequenced; three were identified as catalase and two subunits of alkyl hydroperoxide reductase. Two proteins whose synthesis was repressed in the mutant were sequenced, and one was identified as flagellin. The mutant grew as non-flagellated, partially septate, filaments of cells, and fragments of flagella were seen in the surrounding medium.
\end{abstract}

Keywords: Bacillus subtilis, hydrogen peroxide resistant mutant

\section{INTRODUCTION}

All aerobic organisms generate oxygen free radicals as a result of oxygen metabolism. These include the superoxide radical, $\mathrm{H}_{2} \mathrm{O}_{2}$ and the hydroxyl radical, which are highly reactive with DNA, lipids and proteins. Cells protect themselves against oxidant toxicity either by scavenging the oxidants with enzymes such as catalase, superoxide dismutase and reductases or, in the case of DNA damage, by repairing the damage after it has taken place (Farr \& Kogoma, 1991).

Oxidative stress may be generated experimentally by treating cells with $\mathrm{H}_{2} \mathrm{O}_{2}$. Treatment with high concentrations of this oxidant kills cells, whereas pretreatment with low concentrations can protect the cells against the otherwise lethal effects of high concentrations. This phenomenon has been studied in detail in Salmonella typhimurium, where a $60 \mu \mathrm{M} \mathrm{H}_{2} \mathrm{O}_{2}$ pretreatment protects the cultures against the effects of a $10 \mathrm{mM}$ treatment and causes the induction of at least 30 proteins, as determined

$\dagger$ Present address: Department of Microbiology, Trinity College, Dublin 2 , Ireland.

The PIR accession numbers for the amino acid sequence data reported in this paper are shown in parentheses after the proteins: $78 \mathrm{kDa}$ (A44519), $39 \mathrm{kDa}$ (B44519), $113 \mathrm{kDa}$ (D44519), $54 \mathrm{kDa}$ (E44519), 59.5 kDa (F44519) and 23 kDa (G44519). on two-dimensional gels (Christman et al., 1985). The induction of at least nine of these proteins is positively regulated by the OxyR protein (Christman et al., 1985), which is activated directly by oxidation (Storz et al., 1990). The OxyR-regulated proteins include catalase, alkyl hydroperoxide reductase and glutathione reductase as well as some heat-shock proteins (Christman et al., 1985). Escherichia coli mounts a similar response to $\mathrm{H}_{2} \mathrm{O}_{2}$ (Farr \& Kogoma, 1991). In E. coli, the increased survival after pretreatment with low concentrations of $\mathrm{H}_{2} \mathrm{O}_{2}$ results partly from an increased capacity for DNA repair (Demple \& Halbrook, 1983), but this appears not to be controlled as part of the $0 x y \mathrm{R}$ regulon (Farr \& Kogoma, 1991). A different but overlapping set of proteins are induced by superoxide-radical-generating agents (Greenberg \& Demple, 1989), and the induction of at least six of these proteins is positively regulated by the SoxR and SoxS proteins in E. coli (Wu \& Weiss, 1991).

We have studied the effects of $\mathrm{H}_{2} \mathrm{O}_{2}$ on Bacillus subtilis. These bacteria are Gram-positive obligate aerobes which sporulate in response to some stresses. Thus they might be expected to display a different response to oxidative stress from $E$. coli and $S$. typhimurium. In the case of $B$. subtilis $\mathrm{JH6} 42$, ihere is a $0 \cdot 01-0 \cdot 1 \%$ survival after a $10 \mathrm{~min}$ treatment with $10 \mathrm{mM} \mathrm{H}_{2} \mathrm{O}_{2}$ during the exponential phase of growth. Pretreatment of cultures with $50-100 \mu \mathrm{M}$ $\mathrm{H}_{2} \mathrm{O}_{2}$ results in an approximately 100 -fold increase in survival (Dowds \& Hoch, 1991; Murphy et al., 
1987). During the pretreatment period at least eight proteins are transiently induced, as determined on onedimensional gels (Murphy et al., 1987). Cells with null mutations at the $\operatorname{spo} 0 A$ locus are unable to respond to changes in the environment which would normally lead to sporulation, and are defective in initiating a wide range of stationary-phase events (Trach et al., 1990). These mutants are also about 100 -fold more resistant to the effects of $10 \mathrm{mM} \mathrm{H}_{2} \mathrm{O}_{2}$ than the wild-type (Dowds et al., 1987); this effect is mediated by the $h p r$ pathway as shown by the suppression of the resistance phenotype in spo0 $\mathrm{A}$ mutants by a second mutation in the bpr gene (Dowds \& Hoch, 1991). The $\operatorname{spo} 0 A$ mutation does not affect the inducible phenotype, despite the high level of uninduced resistance to $\mathrm{H}_{2} \mathrm{O}_{2}$ of strains bearing this mutation (Dowds \& Hoch, 1991).

In this study we set out to generate a constitutively resistant mutant of $B$. subtilis which could be used to define the gene regulating induced protection against $\mathrm{H}_{2} \mathrm{O}_{2}$. In addition, it was hoped that the mutant would help us to clone the genes coding for the induced proteins. This task has been difficult due to the non-abundant nature of these proteins and the transience of their induction. Screening of gene fusions for induction by $\mathrm{H}_{2} \mathrm{O}_{2}$ yielded two clones that were induced late (around $1 \mathrm{~h}$ ) following $\mathrm{H}_{2} \mathrm{O}_{2}$ addition. One of these was induced as a consequence of induction of the defective prophage PBSX by $\mathrm{H}_{2} \mathrm{O}_{2}$ (Hartford \& Dowds, 1992). For this reason, the mutant described here was generated from strain YB886, which is uninducible for PBSX and has been cured of another defective prophage $\operatorname{SP} \beta$ (Yasbin et al., 1980). The mutant was found to be constitutively resistant to high concentrations of $\mathrm{H}_{2} \mathrm{O}_{2}$ and accumulated high levels of several proteins, including those induced by $\mathrm{H}_{2} \mathrm{O}_{2}$ in the wild-type.

\section{METHODS}

Mutant selection. The $B$. subtilis strain used in this work was YB886 (trpC2 metB5 xin-1 SP $\beta^{-}$) (Yasbin et al., 1980). The mutant strain MA991 was derived from YB886 as follows. A culture of YB886 was subjected to continuous selection over 16 growth cycles in increasing concentrations of $\mathrm{H}_{2} \mathrm{O}_{2}$, taking the approach of Sauret et al. (1979). The culture was grown in minimal medium (Hartford \& Dowds, 1992) supplemented with Casamino acids $(0.08 \%)(\mathrm{MM}+\mathrm{CAA})$ in $20 \mathrm{ml}$ volumes. In each cycle, the culture was grown for $2 \mathrm{~h}$ before the addition of $\mathrm{H}_{2} \mathrm{O}_{2}$, which was then present for one growth cycle $(10 \mathrm{~h})$. A rolume of $0.3 \mathrm{ml}$ was then diluted into $20 \mathrm{ml}$ medium as before, grown for $2 \mathrm{~h}$, and a higher concentration of $\mathrm{H}_{2} \mathrm{O}_{2}$ was added for $10 \mathrm{~h}$ as before. This continued for 16 growth cycles with the following concentrations (mM) of $\mathrm{H}_{2} \mathrm{O}_{2}$ being added to successive cycles of growth: $0 \cdot 2,1,2,2 \cdot 5,3 \cdot 5,5,7 \cdot 5,11,15,21$, $28,36,44,58,65$ and 74 . After each cycle, cells were plated onto $\mathrm{MM}+\mathrm{CAA}$ agar (MM + CAA with $1.5 \%$ agar) to check for obvious contamination. After the last cycle, the stationaryphase culture was diluted and plated on $\mathrm{MM}+\mathrm{CAA}$ agar and six colonies were picked. Each was grown in $\mathrm{MM}+\mathrm{CAA}$ containing $50 \mathrm{mM} \mathrm{H}_{2} \mathrm{O}_{2}$. All had the same growth rate, which was significantly higher than that of YB886 under the same conditions. One was used for further experiments and named MA991.
Assessment of survival after short-term treatments with $\mathrm{H}_{2} \mathrm{O}_{2}$. Cultures were grown to an $\mathrm{OD}_{550}$ of $0 \cdot 15$. One millilitre amounts were placed in test-tubes containing 0-1 $\mathrm{M} \mathrm{H}_{2} \mathrm{O}_{2}$ and the tubes were shaken at 200 r.p.m. for $15 \mathrm{~min}$ at $37^{\circ} \mathrm{C}$. When cells were subjected to two treatments, the two were sequential and lasted for 15 min each. Survival of the cells was assessed by plating dilutions on LB agar and comparing the viable titre with that of an untreated control tube of culture shaken for the same period of time.

Metabolic labelling of proteins after $\mathrm{H}_{2} \mathrm{O}_{2}$ treatment and SDSPAGE. The procedures used were those described by Murphy et al. (1987).

Enzyme activity. Cultures were grown in MM + CAA medium to an $\mathrm{OD}_{550}$ of $0 \cdot 2$. The cells were lysed with lysozyme (Murphy et al., 1987), and catalase and superoxide dismutase activity were determined by the methods of Aebi (1984) and Darr et al. (1987), respectively. Protein concentration was determined using a BioRad protein assay kit.

Preparation of spore coat proteins. Cultures were grown in Schaeffer sporulation medium (Schaeffer et al., 1965) for 7 or $21 \mathrm{~h}$ after entry into stationary phase ( $t_{7}$ and $t_{21}$, respectively). Spore-coat proteins were extracted by the SDS/D'T'T method of Donovan et al. (1987).

Protein sequencing. Early-exponential-phase $\left(\mathrm{OD}_{550} 0 \cdot 2\right)$ extracts were used for sequencing of all proteins except the $78 \mathrm{kDa}$ protein, which was sequenced from a late-exponentialphase $\left(\mathrm{OD}_{550} 0 \cdot 8\right)$ extract. Samples were prepared for gels as described by Murphy et al. (1987), except that the dye was added after boiling and the early-exponential-phase samples were concentrated 10 -fold on a Centricon 10 (Amicon) after clearing of the lysates. The $12.5 \%(\mathrm{w} / \mathrm{v})$ SDS-PAGE gels were prepared and run as described by Murphy et al. (1987) with the following exceptions. Piperazine diacrylamide was used as a crosslinker $(0.8 \%$ in a $30 \%, \mathrm{w} / \mathrm{v}$, acrylamide stock $)$, and the upper reservoir contained glutathione $(0.05 \mathrm{mM})$ for a prerun at $3 \mathrm{~mA}$ for $2 \mathrm{~h}$ and sodium thioglycolate $(0 \cdot 1 \mathrm{mM})$ for the electrophoresis run after loading of the samples. After electrophoresis, the contents of the gel were blotted onto ProBlott membrane (Applied Biosystems) by the method of Matsudaira (1987), and the protein bands stained with amido black $(0 \cdot 1 \%)$ according to the instructions of Applied Biosystems. $\mathrm{N}$-terminal sequencing was performed at the SERC Protein Sequencing Facility at the University of Aberdeen, Scotland, UK. The sequences were compared to protein and translated DNA sequences in the GenBank database using the program of the National Centre for Bioinformatics in Trinity College Dublin.

Electron microscopic analysis. YB886 and MA991 were grown in LB overnight, and the stationary-phase cultures were placed on carbon-coated grids, negatively stained with $1 \%, w / v$, sodium silicotungstate for $2-3 \mathrm{~min}$ and examined with a transmission electron microscope (Hitachi H-7000, accelerating voltage $100 \mathrm{kV}$ ).

DNA manipulation. All of these methods were as described by Sambrook et al. (1989).

\section{RESULTS}

\section{Isolation of $\mathrm{H}_{2} \mathrm{O}_{2}$-resistant mutant}

An attempt was made to isolate a $\mathrm{H}_{2} \mathrm{O}_{2}$-resistant mutant by selecting mutagenized cells on $\mathrm{LB}$ medium containing $3 \cdot 1 \mathrm{mM} \mathrm{H}_{2} \mathrm{O}_{2}$. No resistant colonies were found by this 

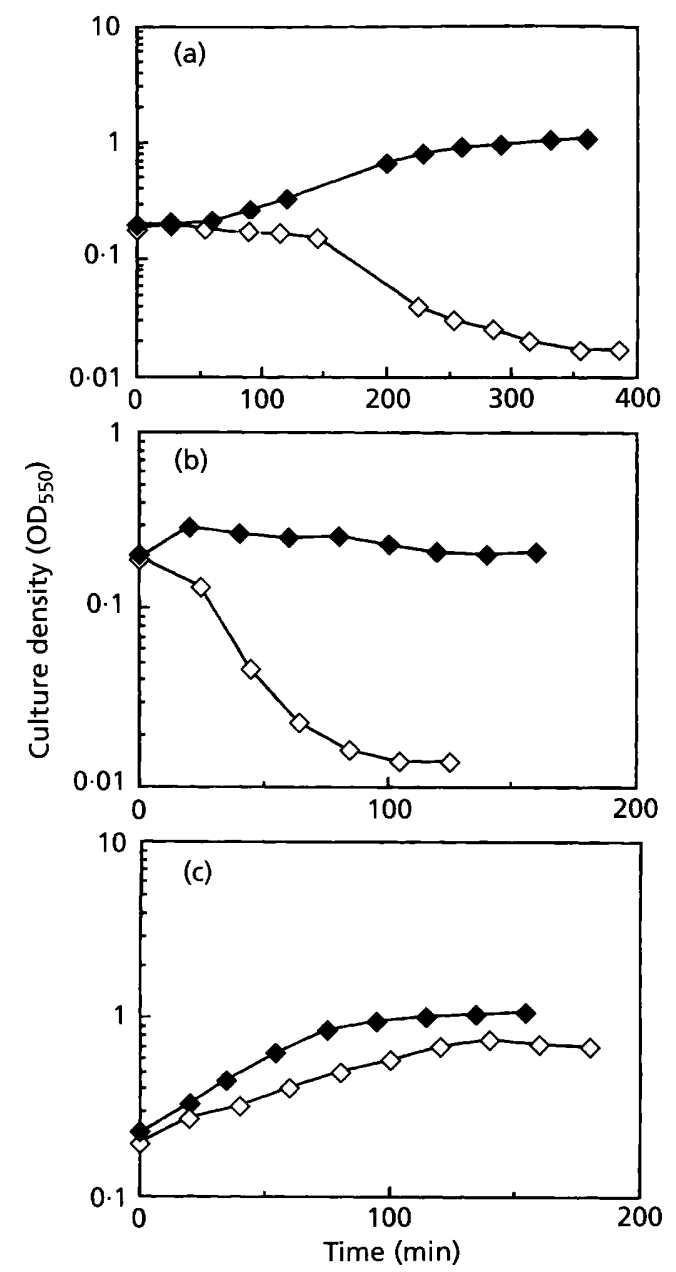

Fig. 1. Effect of (a) $150 \mathrm{mM} \mathrm{H}_{2} \mathrm{O}_{2}$, (b) $1 \mathrm{mM}$ cumene hydroperoxide and (c) $1 \mathrm{mM} t$-butyl hydroperoxide on the growth of YB886 (wild-type, $\diamond$ ) and MA991 (mutant, $\diamond$ ). Cultures were grown in MM + CAA and were treated at an $O D_{550}$ of 0.2 at $t=0 \mathrm{~min}$.

means. Failure to isolate a mutant with this method probably stemmed from difficulty with the selection procedure. The instability of $\mathrm{H}_{2} \mathrm{O}_{2}$ in hot medium probably led to day-to-day variation in the concentration of $\mathrm{H}_{2} \mathrm{O}_{2}$ on the plates and therefore variation in the ability of the wild-type to grow on the medium. Thus an alternative selection method was used in which there was no possibility of the wild-type surviving.

A single colony of YB886 was subjected to continuous selection over 16 growth cycles in increasing concentrations of $\mathrm{H}_{2} \mathrm{O}_{2}$ from $200 \mu \mathrm{M}$ to $74 \mathrm{mM}$. After the last cycle, cells were plated and six colonies were picked for measurement of their growth rates in the presence of $\mathrm{H}_{2} \mathrm{O}_{2}(50 \mathrm{mM})$. All six had the same growth rate, which was considerably higher than that of the wild-type. One of the six was used in further experiments and has been designated MA991. It was a rod-shaped bacterium which was auxotrophic for tryptophan and methionine, like the parent strain YB886.
Table 1. Percentage survival of $B$. subtilis after $\mathrm{H}_{2} \mathrm{O}_{2}$ treatment

With no treatment there was $100 \%$ survival. The values marked $a-b$ were obtained in eight different experiments. $\mathrm{H}_{2} \mathrm{O}_{2}$ was added to cultures for $15 \mathrm{~min}$ starting at an $\mathrm{OD}_{550}$ of $0 \cdot 15$.

\begin{tabular}{|c|c|c|}
\hline \multirow{2}{*}{$\begin{array}{l}{\left[\mathrm{H}_{2} \mathrm{O}_{2}\right]} \\
(\mathrm{mM})\end{array}$} & \multicolumn{2}{|c|}{ Percentage survival } \\
\hline & $\begin{array}{c}\text { MA991 } \\
\text { (mutant) }\end{array}$ & $\begin{array}{c}\text { YB886 } \\
\text { (wild-type) }\end{array}$ \\
\hline 1 & $100^{a}, 96^{b}$ & \\
\hline 10 & $11^{c}$ & $0 \cdot 9^{c}$ \\
\hline 50 & $10^{c}, 11^{d}$ & $0.0003^{c}$ \\
\hline 100 & $11^{d}$ & \\
\hline 150 & $9^{d}$ & \\
\hline 200 & $8^{d}, 7^{e}$ & \\
\hline 350 & $0 \cdot 4^{f}, 0 \cdot 4^{g}, 0 \cdot 2^{h}$ & $<0.00003^{f}$ \\
\hline 500 & $0.05^{e}$ & \\
\hline 1000 & $<0.0001^{e}$ & \\
\hline
\end{tabular}

\section{Growth rate of mutant in presence of peroxides}

MA991 was grown in MM + CAA in the presence of 0,50 , 100,150 and $350 \mathrm{mM} \mathrm{H}_{2} \mathrm{O}_{2}$. It grew well in the first four conditions with doubling times $\left(t_{\mathrm{d}}\right)$ of $33,61,73$ and $85 \mathrm{~min}$, respectively, whereas it failed to grow at the $350 \mathrm{mM}$ concentration. In contrast to the mutant, a culture of the parent strain, YB886, lysed in the presence of $100-350 \mathrm{mM} \mathrm{H}_{2} \mathrm{O}_{2}$ but grew with $t_{\mathrm{d}}$ values of 35 and $200 \mathrm{~min}$ in $\mathrm{MM}+\mathrm{CAA}$ with 0 and $50 \mathrm{mM} \mathrm{H}_{2} \mathrm{O}_{2}$, respectively (see Fig. 1a for the $150 \mathrm{mM}$ concentration). The mutant also grew better than the wild-type in the presence of two other peroxides: cumene hydroperoxide and $t$-butyl hydroperoxide. The culture density of MA991 remained stationary in cumene hydroperoxide $(1 \mathrm{mM})$ whereas YB886 lysed under these conditions (Fig. 1b). In the presence of $t$-butyl hydroperoxide $(1 \mathrm{mM})$, MA991 had a $t_{\mathrm{d}}$ of $35 \mathrm{~min}$ compared to a $t_{\mathrm{d}}$ of $67 \mathrm{~min}$ for the wildtype (Fig. 1c).

\section{Survival of MA991 after short-term $\mathrm{H}_{2} \mathrm{O}_{2}$ treatment}

Table 1 shows the percentage survival of MA991 and YB886 after 15 min treatments with $\mathrm{H}_{2} \mathrm{O}_{2}$. The mutant displayed a similar response of $7-11 \%$ survival to treatments of $10-200 \mathrm{mM}$. The wild-type parent strain was more sensitive to 10 and $50 \mathrm{mM}$ concentrations than was the mutant and, in addition, the wild-type was considerably more sensitive to the higher than the lower concentration.

Pretreatment of the wild-type strain with $100 \mu \mathrm{M}$ of the oxidant partially protected it against the higher concentrations, but the mutant did not display any such inducible protection (Table 2 ). This protective concentration was 
Table 2. Percentage survival of $B$. subtilis after pretreatment with low concentrations followed by treatment with high concentrations of $\mathrm{H}_{2} \mathrm{O}_{2}$

With no treatment there was $100 \%$ survival. The values marked $a$ and $b$ were obtained in two different experiments. Cultures were treated at an $O D_{550}$ of 0.15 for $15 \mathrm{~min}$. Samples subjected to two treatments were treated sequentially.

\begin{tabular}{|lcc|}
\hline$\left[\mathbf{H}_{2} \mathbf{O}_{2}\right]$ & \multicolumn{2}{c|}{ Percentage survival } \\
\cline { 2 - 3 } & $\begin{array}{c}\text { MA991 } \\
\text { (mutant) }\end{array}$ & $\begin{array}{c}\text { YB886 } \\
\text { (wild-type) }\end{array}$ \\
\hline $100 \mu \mathrm{M}$ & $100^{b}$ & $100^{a}, 100^{b}$ \\
$10 \mathrm{mM}$ & $11^{b}$ & $0 \cdot 2^{a}, 0 \cdot 9^{b}$ \\
$100 \mu \mathrm{M}, 10 \mathrm{mM}$ & $10^{b}$ & $8^{a}, 12^{b}$ \\
$50 \mathrm{mM}$ & $10^{b}$ & $0 \cdot 0003^{b}$ \\
$100 \mu \mathrm{M}, 50 \mathrm{mM}$ & $9^{b}$ & $0 \cdot 002^{b}$ \\
\hline
\end{tabular}

Table 3. Percentage survival of mutant MA991 after pretreatment and treatment with a variety of $\mathrm{H}_{2} \mathrm{O}_{2}$ concentrations

With no treatment there was $100 \%$ survival. The values marked $a-e$ were obtained in five different experiments. Cultures were treated at an $\mathrm{OD}_{550}$ of $0 \cdot 15$ for $15 \mathrm{~min}$. Samples subjected to two treatments were treated sequentially.

\begin{tabular}{|lll|}
\hline $\begin{array}{l}\text { Pretreatment } \\
{\left[\mathbf{H}_{2} \mathbf{O}_{2}\right]}\end{array}$ & \multicolumn{1}{c|}{$\begin{array}{c}\text { Treatment } \\
{\left[\mathbf{H}_{2} \mathbf{O}_{2}\right]}\end{array}$} & \multicolumn{1}{c|}{$\begin{array}{c}\text { Percentage } \\
\text { survival }\end{array}$} \\
\hline $100 \mu \mathrm{M}$ & $100 \mu \mathrm{M}$ & $100^{a . b . c}$ \\
& $400 \mathrm{mM}$ & $0 \cdot 0008^{a}$ \\
& $100 \mu \mathrm{M}, 400 \mathrm{mM}$ & $0 \cdot 0008^{a}$ \\
& $500 \mathrm{mM}$ & $0 \cdot 0001^{a}, 0 \cdot 003^{b}, 0 \cdot 05^{c}$ \\
& $100 \mu \mathrm{M}, 500 \mathrm{mM}$ & $0 \cdot 0001^{a}, 0 \cdot 008^{b}, 0 \cdot 3^{c}$ \\
& $1 \mathrm{M}$ & $<0 \cdot 0001^{c}$ \\
$500 \mu \mathrm{M}$ & $100 \mu \mathrm{M}, 1 \mathrm{M}$ & $<0 \cdot 0001^{c}$ \\
& $500 \mu \mathrm{M}$ & $100^{d}$ \\
& $200 \mathrm{mM}$ & $43^{d}$ \\
& $500 \mu \mathrm{M}, 200 \mathrm{mM}$ & $90^{d}$ \\
& $300 \mathrm{mM}$ & $34^{d}$ \\
& $500 \mu \mathrm{M}, 300 \mathrm{mM}$ & $15^{d}$ \\
& $1 \mathrm{mM}$ & $96^{e}$ \\
& $350 \mathrm{mM}$ & $5^{e}$ \\
& $1 \mathrm{mM}, 350 \mathrm{mM}$ & $3^{e}$ \\
& $400 \mathrm{mM}$ & $1^{e}$ \\
& $1 \mathrm{mM}, 400 \mathrm{mM}$ & $0 \cdot 4^{e}$ \\
& $450 \mathrm{mM}$ & $0 \cdot 01^{e}$ \\
& $1 \mathrm{mM}, 450 \mathrm{mM}$ & $0 \cdot 002^{e}$ \\
\hline
\end{tabular}

determined as the highest concentration which did not affect the viability of the wild-type strain, while the concentration of $10 \mathrm{mM}$ was that which gave rise to survival of $0 \cdot 1-1 \%$ of the wild-type strain YB886. Thus these were not necessarily suitable concentrations for assessing the inducibility of the mutant. Therefore pro-

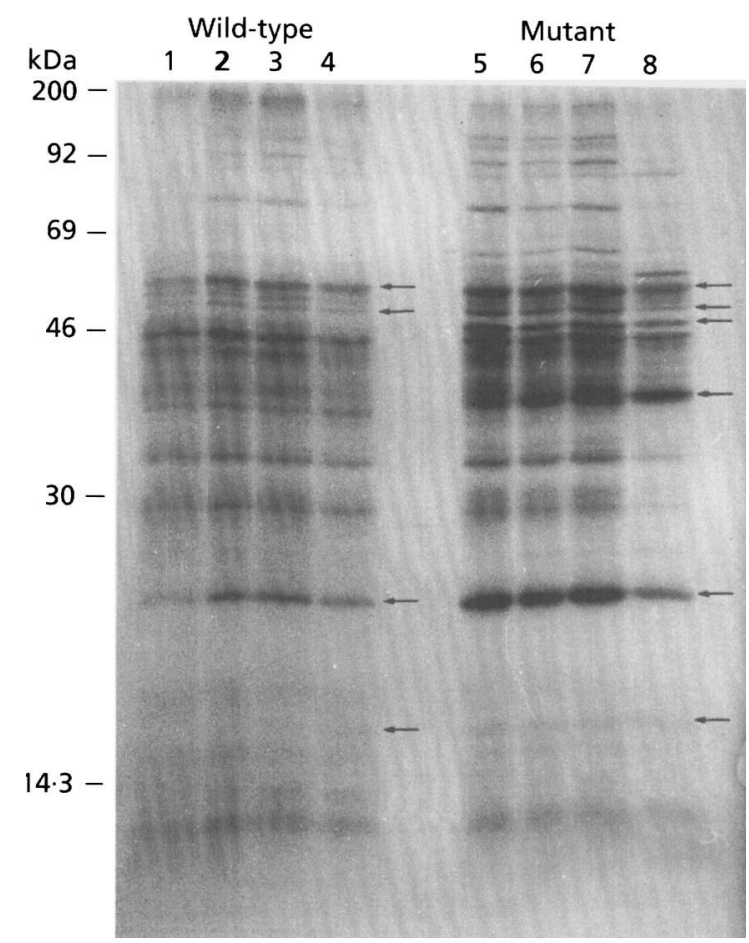

Fig. 2. Autoradiogram of SDS-PAGE gel (12.5\%) of [35 S]methionine-labelled proteins from YB886 (wild-type) (lanes 1-4) and MA991 (mutant) (lanes 5-8). Cells grown to an $O_{550}$ of 0.2 were pulse labelled for $5 \mathrm{~min}$, as described by Murphy et al. (1987), in the absence of $\mathrm{H}_{2} \mathrm{O}_{2}$ treatment (lanes 1 and 5); 0-5 min (lanes 2 and 6) and 5-10 min (lanes 3 and 7) after $100 \mu \mathrm{M} \mathrm{H}_{2} \mathrm{O}_{2}$ treatment; and $0-5 \mathrm{~min}$ after $1 \mathrm{mM} \mathrm{H}_{2} \mathrm{O}_{2}$ treatment (lanes 4 and 8). The arrows beside lane 4 indicate the proteins induced by $\mathrm{H}_{2} \mathrm{O}_{2}$ in $\mathrm{YB886}$, while the arrows beside lane 8 show the proteins whose rate of synthesis is greater in MA991 than in YB886 (after induction). The positions of molecular mass markers are indicated on the left.

tective and killing concentrations were established for MA991 to determine whether the mutant had an inducible response to $\mathrm{H}_{2} \mathrm{O}_{2}$. The effect of a range of concentrations on the mutant (Table 1 ) revealed that concentrations of $200-500 \mathrm{mM}$ had to be used in order to effect survival of $0.05-8 \%$. A concentration of $1 \mathrm{mM}$ had no effect on viability of MA991, while $10 \mathrm{mM}$ killed $90 \%$ of the cells. Thus concentrations of $1 \mathrm{mM}$ down to the wild-type level of $100 \mu \mathrm{M}$ were used to attempt to protect MA991 against killing concentrations of $200-1000 \mathrm{mM} \mathrm{H}_{2} \mathrm{O}_{2}$ ('Table 3). None of the pairs of concentrations used suggested an inducible response in the mutant, implying that MA991 is constitutively resistant to $\mathrm{H}_{2} \mathrm{O}_{2}$.

\section{Protein synthesis in wild-type and mutant with and without $\mathrm{H}_{2} \mathrm{O}_{2}$ treatment}

Cells grown to mid-exponential-phase were pulse-labelled with $\left[{ }^{35} \mathrm{~S}\right]$ methionine for $5 \mathrm{~min}$ in the absence of $\mathrm{H}_{2} \mathrm{O}_{2}$ treatment and from $0-5$ and $5-10$ min after addition of inducing concentrations of $\mathrm{H}_{2} \mathrm{O}_{2}(100 \mu \mathrm{M}$ and $1 \mathrm{mM})$ (Fig. 2). In the wild-type strain YB886, synthesis of four proteins was induced by $\mathrm{H}_{2} \mathrm{O}_{2}$ (compare lane 1 with lanes 


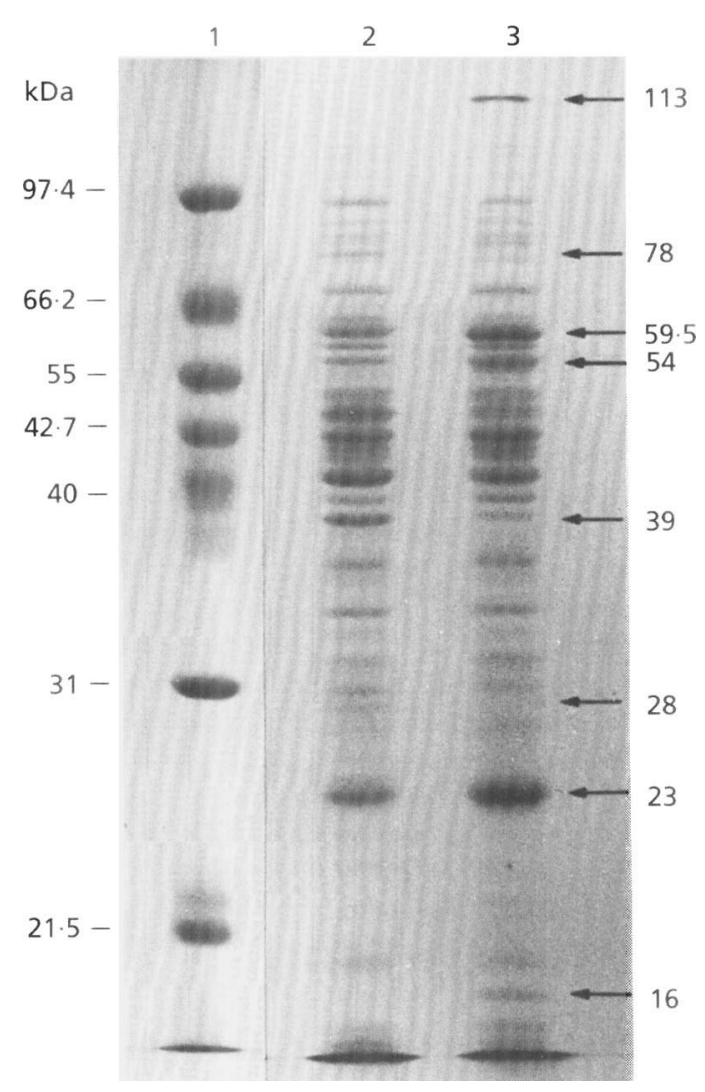

Fig. 3. SDS-PAGE gel (12.5\%) of cleared lysates of YB886 (wildtype) (lane 2) and MA991 (mutant) (lane 3) stained with Coomassie blue. Cultures were grown to an $\mathrm{OD}_{550}$ of 0.8 and samples prepared as described by Murphy et al. (1987). Arrows indicate the position of proteins which accumulate to different extents in the two strains. Lane 1 , molecular mass markers.

2-4, Fig. 2). These proteins of $16,23,54$ and $59 \cdot 5 \mathrm{kDa}$ are four of the six proteins previously observed to be induced immediately following $\mathrm{H}_{2} \mathrm{O}_{2}$ treatment of another wildtype strain, JH642 (Murphy et al., 1987). No proteins were induced in the mutant MA991 following $\mathrm{H}_{2} \mathrm{O}_{2}$ treatment (Fig. 2, lanes 5-8). However, a comparison of the mutant and the wild-type reveals that several proteins were synthesized at a much higher rate in the mutant. They include the four proteins induced in YB886 which were synthesized in the mutant at a rate even higher than the induced wild-type rate. In addition, proteins of 40 and $50 \mathrm{kDa}$ were synthesized at a higher rate in the mutant (Fig. 2), and synthesis of a $39 \mathrm{kDa}$ protein which was constitutive in the wild-type was not detected at all in the mutant.

\section{Protein accumulation in wild-type and mutant}

Lysates of the cell pellets of YB886 and MA991 were run on an SDS-PAGI: gel and stained with Coomassie blue (Fig. 3). Proteins of 16, 23, 54, 59.5 and $113 \mathrm{kDa}$ accumulated to a greater extent in the mutant than in the wild-type. In addition, the $40 \mathrm{kDa}$ protein was repeatedly

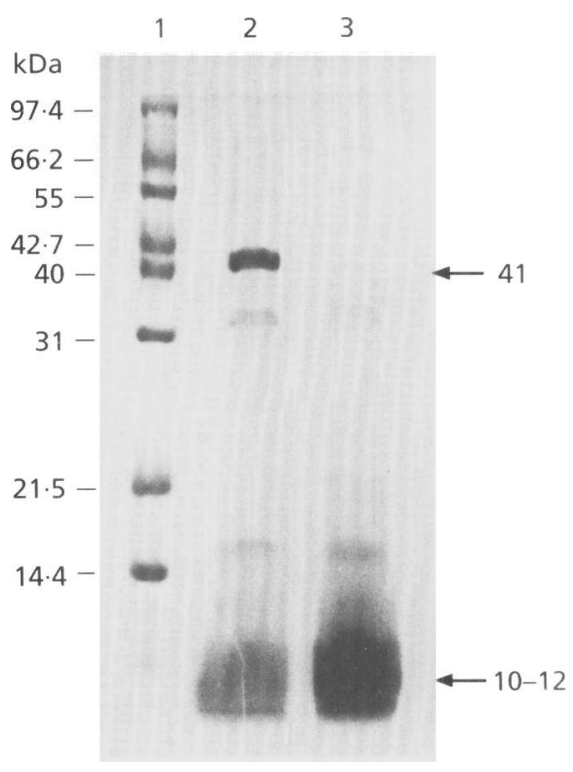

Fig. 4. Coomassie-blue-stained SDS-PAGE gel (15\%) of sporecoat proteins prepared from YB886 (wild-type) (lane 2) and MA991 (mutant) (lane 3) cultures grown to $t_{7}$. Arrows indicate proteins which accumulate to a different extent in the two strains. Lane 1, molecular mass markers.

observed to over-accumulate in the mutant compared to the wild-type, but this difference cannot be seen on the gel shown in Fig. 3. The $50 \mathrm{kDa}$ protein which was synthesized at a higher rate in the mutant (Fig. 2) was not seen on the Coomassie blue-stained gels (Fig. 3), and is presumably a low-abundance protein. The $113 \mathrm{kDa}$ protein which over-accumulated in the mutant (Fig. 3) was not clearly identifiable on the protein synthesis gels (Fig. 2). Proteins of 28,39 and $78 \mathrm{kDa}$ accumulated to a much smaller extent in the mutant. The difference in the accumulation of the $78 \mathrm{kDa}$ protein was seen only in lateexponential-phase samples. All of the other differences were observed in both early- and late-exponential-phase samples.

\section{Analysis of spore-coat proteins in MA991}

MA991 appeared as brown colonies after $1 \mathrm{~d}$ growth on LB agar, unlike YB886, whose colonies are white in colour. The brown colour of MA991 intensified with time, suggesting that the colour might be associated with the formation of spores, whose brown pigment is a $65 \mathrm{kDa}$ spore-coat protein encoded by the $\cot A$ gene (Donovan et al., 1987). Thus, the spore-coat proteins of the mutant and wild-type were compared. The $65 \mathrm{kDa}$ protein was a low-abundance protein under the conditions of growth and extraction used here, and there was no difference in the intensity of this band between the two strains (Fig. 4). However, two major spore-coat proteins accumulated to different extents in YB886 and MA991 at $t_{7}$, defined as $7 \mathrm{~h}$ after entry into stationary phase (Nicholson \& Setlow, 1990). A $41 \mathrm{kDa}$ protein underaccumulated in the mutant, while a thick band of 


\author{
Protein Sequence from $\mathrm{N}$-terminus \\ $78 \mathrm{kDa}$ ? K V S ? DEGN? N A E V A D \\ (L) \\ $39 \mathrm{kDa} \quad$ MRINHNIAALNTLNRLS? \\ Flagellin MRINH I A A L NTLNRLSSN NSASQKNMEK \\ (a) \\ 113 kDa ? K T EN AKT N Q T L VENKST T QT VFR M H
}

(A)

59.5 kDa S S K L T? SW G A P V G D QN

Catalase MSSNKLTTSWGAPVGDNQN

(b)

$54 \mathrm{kDa}$

M VLDANIKA Q L N Y M Q I END? L K V? A E

AhpF

M LDTNMKTOLRAYLEKLTKPVELIATLD

(c)

(M)

$23 \mathrm{kDa}$

(E)

AhpC

S LIGKEVLPFEAKAFKNGEFIDVT NEDLK

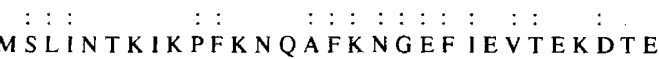

(d)

$23 \mathrm{kDa}$

(D)

AhpC

G Q W S V F ? ? Y P A

GRWSVFFFYPA

Fig. 5. N-terminal amino acid sequences of proteins which under-accumulate (78 and $39 \mathrm{kDa}$ ) or over-accumulate (remainder) in MA991 (mutant) relative to YB886 (wild-type). Letters in parentheses show an alternative possibility for a particular amino acid, and a question mark indicates where the identity of the amino acid was not clear. Four of the sequences displayed partial or complete identity to published $\mathrm{N}$-terminal protein sequences. In these cases the published sequence is shown underneath. (a) B. subtilis flagellin amino acid sequence (Delange et al., 1976); (b) B. subtilis catalase deduced from DNA sequence (Bol \& Yasbin, 1991); (c) S. typhimurium alkyl hydroperoxide reductase subunit F52a deduced from DNA sequence of the ahpF gene (Tartaglia et al., 1991); (d) $S$. typhimurium alkyl hydroperoxide reductase subunit C22 deduced from DNA sequence of the ahpC gene (Tartaglia et al., 1991). Double dots indicate positions of identity between the two sequences.

10-12 kDa over-accumulated (Fig. 4). In other gels, this thick lower band separated into two, and the $10 \mathrm{kDa}$ protein was much more intense in the mutant than the wild-type. Other minor differences between the two lanes can be seen in Fig. 4 but these were not reproducible. In order to check that the proteins extracted were indeed derived from spores and not vegetative cells, cultures grown to $t_{7}$ and $t_{21}$ were harvested and the spores separated on Urografin gradients (Nicholson \& Setlow, 1990). The same differences between the strains were observed at $t_{7}$. However, at $t_{21}$, there were no differences between the two strains, and the $41 \mathrm{kDa}$ band was not visible in either sample (data not shown).

\section{Scavenging enzyme activity in MA991}

Catalase activity was measured at early -exponential-phase in the mutant and wild-type. In one experiment, the specific activities were 135 and 497 units $\mathrm{mg}^{-1}$ and in a

second experiment they were 133 and 1005 units $\mathrm{mg}^{-1}$ in YB886 and MA991, respectively. Thus, the specific activity of catalase is $3 \cdot 7-7 \cdot 5$-fold greater in the mutant than in the wild-type. The specific activity of superoxide dismutase was found to be the same in YB886 and MA991 (data not shown).

\section{$\mathrm{N}$-terminal sequence of proteins differentially expressed in MA991}

N-terminal sequence analysis was performed on the proteins differentially expressed in the mutant relative to the wild-type (Fig. 5). The data were compared to other protein sequences in GenBank. This revealed that the $59 \cdot 5$ and $39 \mathrm{kDa}$ proteins were identical to the published sequences for B. subtilis catalase (Bol \& Yasbin, 1991) and flagellin (DeLange et al., 1976), respectively. The 23 and $54 \mathrm{kDa}$ proteins were similar to the C22 (AhpC) and F52a (AhpF) subunits, respectively, of the alkyl hydroperoxide reductase of $S$. typhimurium (Tartaglia et al., 1990). The $23 \mathrm{kDa}$ protein had 24 out of 41 amino acids identical to the $\mathrm{C} 22$ protein. In the case of the $54 \mathrm{kDa}$ protein, 8 of the first 13 amino acids of F52a were identical to those of the $54 \mathrm{kDa}$ protein, after which their sequences diverged and did not show any similarity.

\section{MA991 grows in non-flagellated filaments}

The observation that flagellin under-accumulated in mutant relative to wild-type cells prompted an examination of the flagella of MA991 by microscopy. Under the light microscope, it could be seen that YB886 consisted of motile rods, whereas MA991 consisted of non-motile filaments (data not shown). By electron microscopy, the wild-type was found, as expected, to be rod shaped with multiple peritrichous flagella (Fig. 6a). MA991, on the other hand, grew in filaments and the cells lacked attached flagella (Fig. 6b). When a more dense culture (also stationary phase) of MA991 was examined, the filaments were found to be shorter (data not shown). The levels of autolysins were measured and found to be identical in the two strains (data not shown). Examination of the mutant culture medium revealed fragments of flagella not attached to the cells (Fig. 6c).

\section{DISCUSSION}

A peroxide-resistant mutant, MA991, was isolated by selection in increasing concentrations of $\mathrm{H}_{2} \mathrm{O}_{2}$. Such stepwise selection procedures sometimes lead to amplification of the DNA containing a resistance gene (Hornemann et al., 1987). This possibility was ruled out for MA991 by finding that the pattern and intensity of bands in restriction digests of DNA was the same for the mutant and wild-type (data not shown). Furthermore, it has been noted that strains which are stress-resistant as a result of DNA amplification are unstable when grown in the absence of the stress (Goldberg \& Mekalanos, 1986) but the resistance of MA991 was retained after prolonged growth in the absence of $\mathrm{H}_{2} \mathrm{O}_{2}$ (data not shown). These results show that the mutant was stable and did not arise 

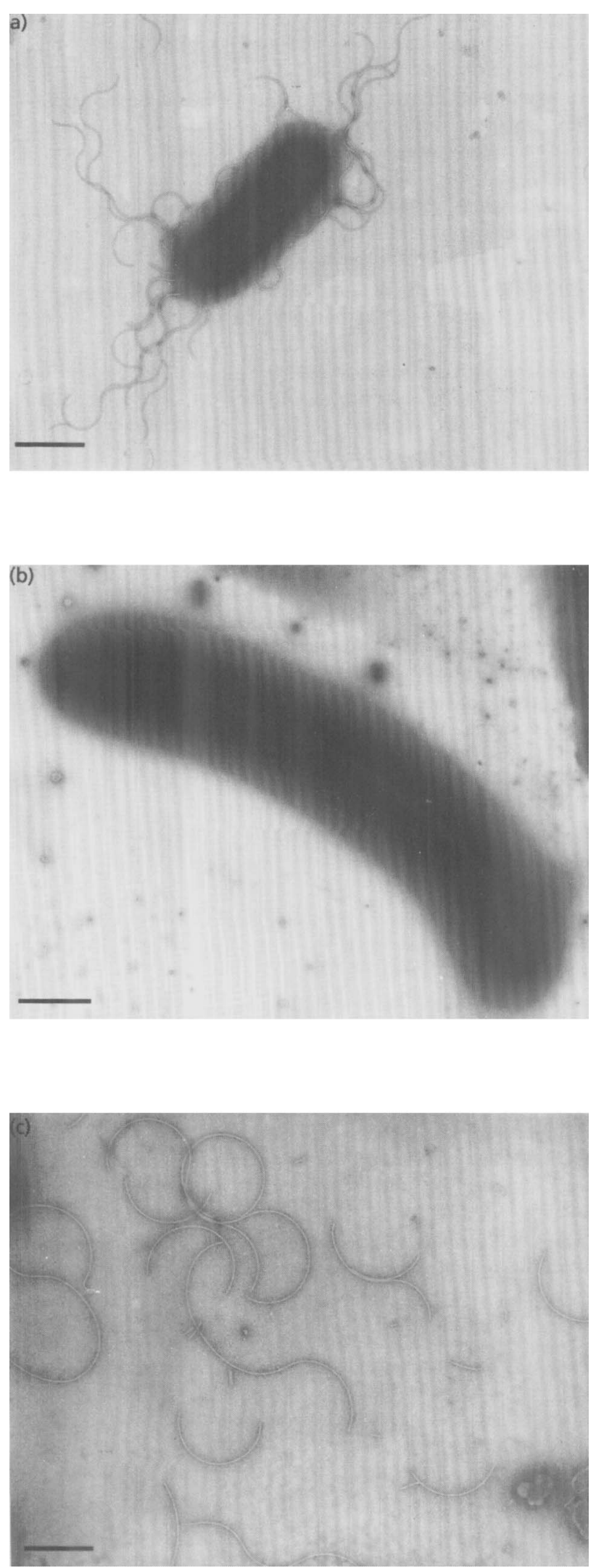

Fig. 6. Cells of (a) YB886 (wild-type) and (b) MA991 (mutant) and (c) flagella fragments of MA991 examined by transmission electron microscopy. Bars: (a) $1.43 \mu \mathrm{m}$; (b) $588 \mathrm{~nm}$; (c) $3.3 \mu \mathrm{m}$. from large-scale rearrangement or amplification of a region of the genome.

MA991 was highly resistant to short- and long-term exposure to $\mathrm{H}_{2} \mathrm{O}_{2}$, and was less sensitive than the wildtype to cumene hydroperoxide and $t$-butyl hydroperoxide. The resistance to $\mathrm{H}_{2} \mathrm{O}_{2}$ was constitutive and could not be further induced by treatment with low concentrations of $\mathrm{H}_{2} \mathrm{O}_{2}$. However, the mutant was no more resistant than the wild-type to cadmium chloride, mitomycin $\mathrm{C}$, paraquat, plumbagin, $\mathrm{N}$-ethylmaleimide or a $57^{\circ} \mathrm{C}$ heat shock (data not shown). Protein synthesis and accumulation was examined in the two strains. Four proteins that were induced by $\mathrm{H}_{2} \mathrm{O}_{2}$ in the wild-type were constitutively synthesized at a high rate in the mutant (higher than in the induced wild-type). Three of these were identified as catalase and two subunits of alkyl hydroperoxide reductase, which degrade $\mathrm{H}_{2} \mathrm{O}_{2}$ and organic hydroperoxides (including cumene hydroperoxide and $t$-butyl hydroperoxide), respectively (Storz et al., 1989). The quality of filamentation is another attribute of the mutant found in wild-type $B$. subtilis treated with $\mathrm{H}_{2} \mathrm{O}_{2}(3 \mathrm{mM}$ ) (Bol \& Yasbin, 1990). The lack of attached flagella in MA991 probably derives directly from its filamentation, as these two characteristics have been associated in a variety of mutants studied (e.g. Helmann et al., 1988).

In summary, MA991 is constitutively resistant to high concentrations of $\mathrm{H}_{2} \mathrm{O}_{2}$, it synthesizes all of the proteins induced by $\mathrm{H}_{2} \mathrm{O}_{2}$ in the wild-type and it grows as filaments of cells. Thus, MA991 has a collection of attributes that can be induced in the wild-type in response to $\mathrm{H}_{2} \mathrm{O}_{2}$ treatment. This is consistent with MA991 being affected in a gene controlling a peroxide-response regulon. Attempts were made to isolate this regulatory gene by trying to transform YB886 to $\mathrm{H}_{2} \mathrm{O}_{2}$ resistance with a bank of MA991 DNA on an integrating plasmid. These attempts were unsuccessful, and it is not clear whether MA991 possesses more than one mutation or whether the problem lay in the selection conditions used. Thus it is not clear whether the multiple traits of MA991 derive from a single or multiple mutations. However, it is probable that MA991 has been affected in at least one regulatory gene involved in induced resistance to $\mathrm{H}_{2} \mathrm{O}_{2}$.

We have previously shown that a spo0 A mutant JH646, which is defective in responding to conditions which activate sporulation, is 100 -fold more resistant to $\mathrm{H}_{2} \mathrm{O}_{2}$ than its wild-type parent, JH642 (Dowds et al., 1987; Dowds \& Hoch, 1991). However, some further resistance of this mutant can be induced by low concentrations of $\mathrm{H}_{2} \mathrm{O}_{2}$ (Dowds \& Hoch, 1991). In addition, while only two of the proteins induced in the wild-type are also induced in the $s p o 0 A$ strain, most of the remaining proteins are not synthesized at a high level in the mutant. The only exception is the $20 \mathrm{kDa}$ protein (the JH646 equivalent of the $23 \mathrm{kDa}$ protein of MA991), which is constitutively synthesized in the spoOA mutant at approximately the same rate as in the induced wild-type (Dowds et al., 1987). Thus, it appears that a gene for alkyl hydroperoxide reductase is expressed constitutively in both MA991 and in the spo0 A mutant JH646. However, it is clear that MA991 and JH646 contain different 
regulatory mutations, the former affecting the inducible phenotype and the latter affecting the basal, uninduced sensitivity to $\mathrm{H}_{2} \mathrm{O}_{2}$.

\section{ACKNOWLEDGEMENTS}

We thank Bryan Dunbar for performing the protein sequencing. Colin Reid for help with the electron microscopy and Siobhan Byrne for performing the autolysin assays. This work was supported by Eolas, the Irish Science and Technology Agency.

\section{REFERENCES}

Aebi، H. (1984). Catalase in vitro. Methods Enzymol 105, 121-126.

Bol, D. K. \& Yasbin, R. E. (1990). Characterization of an inducible oxidative stress system in Bacillus subtilis. J Bacteriol 172, 3503-3506.

Bol, D. K. \& Yasbin, R. E. (1991). The isolation, cloning and identification of a vegetative catalase gene from Bacillus subtilis. Gene 109, 31-37.

Christman, M. K., Morgan, R. W., Jacobson, F. S. \& Ames, B. N. (1985). Positive control of a regulon for defences against oxidative stress and some heat-shock proteins in Salmonella typhimurium. Cell 41, 753-762.

Darr, D., Zarilla, K. A. \& Fridovich, I. (1987). A mimic of superoxide dismutase activity based upon desferrioxamine $\mathrm{B}$ and manganese (IV). Arch Biochem Biophys 258, 351-355.

DeLange, R. J., Chang, J. Y., Shaper, J. H. \& Glazer, A. N. (1976). Amino acid sequence of flagellin of Bacillus subtilis 168. J Biol Chem 251, 705-711

Demple, B. \& Halbrook, J. (1983). Inducible repair of oxidative DNA damage in Eschericbia coli. Nature 304, 466-468.

Donovan, W., Zheng, L., Sandman, K. \& Losick, R. (1987). Genes encoding spore coat polypeptides from Bacillus subtilis. J Mol Biol 196, 1-10.

Dowds, B. C. A. \& Hoch, J. A. (1991). Regulation of the oxidative stress response by the hpr gene in Bacillus subtilis. J Gen Microbiol 137, 1121-1125.

Dowds, B. C. A., Murphy, P., McConnell, D. \& Devine, K. M. (1987). Relationship among oxidative stress, growth cycle, and sporulation in Bacillus subtilis. J Bacteriol 169, 5771-5775.

Farr, S. B. \& Kogoma, T. (1991). Oxidative stress responses in Eschericbia coli and Salmonella typhimurium. Microbiol Rev 55, 561-585.

Goldberg, I. \& Mekalanos, J. J. (1986). Effect of a rec $A$ mutation on cholera toxin gene amplification and deletion events. J Bacteriol $\mathbf{1 6 5}$, 723-731.

Greenberg, J. T. \& Demple, B. (1989). A global response induced in Eschericbia coli by redox-cycling agents overlaps with that induced by peroxide stress. J Bacteriol 171, 3933-3939.

Hartford, O. \& Dowds, B. C. A. (1992). Cloning and characterization of genes induced by hydrogen peroxide in Bacillus subtilis. J Gen Microbiol 138, 2061-2068.
Helmann, J. D., Marquez, L. M. \& Chamberlin, M. J. (1988). Cloning, sequencing, and disruption of the Bacillus subtilis $\sigma^{28}$ gene. $J$ Bacteriol 170, 1568-1574.

Hornemann, U., Otto, C. J., Hoffman, G. G. \& Bertinuson, A. C. (1987). Spectinomycin resistance and associated DNA amplification in Streptomyces acbromogenes subsp. rubradiris. J Bacteriol 169, $2360-2366$.

Matsudaira, P. (1987). Sequence from picomole quantities of proteins electroblotted onto polyvinylidene difluoride membranes. $J$ Biol Chem 262, 10035-10038.

Murphy, P., Dowds, B. C. A., McConnell, D. J. \& Devine, K. M. (1987). Oxidative stress and growth temperature in Bacillus subtilis. $J$ Bacteriol 169, 5766-5770.

Nicholson, W. L. \& Setlow, P. (1990). Sporulation, germination and outgrowth. In Molecular Biological Methods for Bacillus, pp. 391-450. Edited by C. R. Harwood \& S. M. Cutting. Chichester: John Wiley.

Sambrook, J., Fritsch, E. F. \& Maniatis, T. (1989). Molecular Cloning: A Laboratory Manual, 2nd edn. Cold Spring Harbor, NY: Cold Spring Harbor Laboratory.

Sauret, G., Jouve, H. \& Pelmont, J. (1979). Propriétés d'un mutant de Proteus mirabilis résistant au peroxyde d'hydrogène. Canadian J Microbiol 25, 312-320.

Schaeffer, P., Miller, T. \& Aubert, J. (1965). Catabolic repression of bacterial sporulation. Proc Natl Acad Sci USA 54, 701-711.

Storz, G., Jacobson, F. S., Tartaglia, L. A., Morgan, R. W., Silveira, L. A. \& Ames, B. N. (1989). An alkyl hydroperoxide reductase induced by oxidative stress in Salmonella typhimurium and Escherichia coli: genetic characterization and cloning of ahp. J Bacteriol 171, 2049-2055.

Storz, G., Tartaglia, L. A. \& Ames, B. N. (1990). Transcriptional regulator of oxidative stress-inducible genes: direct activation of oxidation. Science 248, 189-194.

Tartaglia, L. A., Storz, G., Brodsky, M. H., Lai, A. \& Ames, B. N. (1990). Alkyl hydroperoxide reductase from Salmonella typhimurium. $J$ Biol Chem 265, 10535-10540.

Trach, K., Burbulys, D., Spiegelman, G., Perego, M., Van Hoy, B., Strauch, M., Day, J. \& Hoch, J. A. (1990). Phosphorylation of the Spo0A protein: a cumulative environsensory activation mechanism. In Genetics and Biotechnology of Bacilli, vol. 3, pp. 357-365. Edited by M. M. Zukowski, A. T. Ganesan \& J. A. Hoch. San Diego: Academic Press.

Wu, J. \& Weiss, B. (1991). Two divergently transcribed genes, soxR and soxS, control a superoxide response regulon of Escherichia coli. $J$ Bacteriol 173, 2864-2871.

Yasbin, R. E., Fields, P. I. \& Anderson, B. J. (1980). Properties of Bacillus subtilis 168 derivatives freed of their natural prophages. Gene 12, 155-159.

Received 27 May 1993; revised 12 August 1993; accepted 19 August 1993. 